\title{
Use of psychoactive substances in women in outpatient treatment
}

\author{
Uso de substâncias psicoativas em mulheres em tratamento ambulatorial \\ Uso de sustancias en mujeres en tratamiento ambulatorio
}

\section{Jessica Adrielle Teixeira Santos' \\ ORCID: 0000-0002-8823-7170 \\ Ludmila Gonçalves Perruci' \\ ORCID: 0000-0001-5655-4115}

Natália Priolli Jora Pegoraro' ORCID: 0000-0001-9868-7071

Zeyne Alves Pires Scherer ORCID: 0000-0002-3162-5957

Jacqueline de Souza'

ORCID: 0000-0002-6094-6012

Manoel Antônio dos Santos'

ORCID: 0000-0001-8214-7767

Sandra Cristina Pillon'

ORCID: 0000-0001-8902-7549

'Universidade de São Paulo. Ribeirão Preto, São Paulo, Brazil.

How to cite this article:

Santos JAT, Perruci LG, Pegoraro NPJ, Scherer ZAP

Souza J, Santos MA, et al. Use of psychoactive substances in women in outpatient treatment.

Rev Bras Enferm. 2019;72(Suppl 3):178-83. doi: http://dx.doi.org/10.1590/0034-7167-2018-0399

\section{Corresponding Author:}

Jessica Adrielle Teixeira Santos

E-mail: jessicadrielle@yahoo.com.br/ jessicadrielle@usp.br

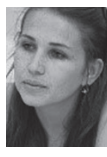

Submission: 06-07-2018 Approval: 08-18-2018

\section{ABSTRACT}

Objective: to characterize the sociodemographic and psychiatric profile of women users of psychoactive substances in treatment for drug addiction. Method: descriptive study of quantitative approach performed with women attended at a Psychosocial Care Center for Users of Alcohol and Other Drugs (CAPS ad) from the interior of São Paulo State. Results: the sample consisted of 349 adult women, single, low educational level and unemployed, users of alcohol, cocaine, crack and tranquillizers. Among the consequences of use include withdrawal syndrome, overdose, depressive and suicidal symptoms. Most were referred for treatment by the family or health services. Almost $20 \%$ of these women had previously started treatments. Conclusion: The results suggest marked morbidity and high levels of psychosocial vulnerability, which require thorough investigation at the patient's admission, as well as damage associated with use, withdrawal symptoms and depressive symptoms. Descriptors: Substance-Related Disorders; Women's Health; Health Profile; Outpatient Care; Mental Health

\section{RESUMO}

Objetivo: caracterizar o perfil sociodemográficos e psiquiátrico de mulheres usuárias de substâncias psicoativas em tratamento para dependência química. Método: estudo descritivo de abordagem quantitativa realizado com mulheres atendidas em um Centro de Atenção Psicossocial para Usuários de Álcool e outras Drogas (CAPS ad) do interior paulista. Resultados: a amostra foi de 349 mulheres adultas, solteiras, baixa escolaridade e desempregadas, usuárias de álcool, cocaína, crack e tranquilizantes. Entre as consequências do uso incluem a síndrome de abstinência, overdose, sintomas depressivos e suicidas. A maioria foi encaminhada para o tratamento pela família ou serviços de saúde. Quase $20 \%$ dessas mulheres já havia iniciado tratamentos anteriormente. Conclusão: Os resultados sugerem acentuada morbidade e elevados níveis de vulnerabilidade psicossocial, que requerem investigação minuciosa na admissão da usuária, além de danos associados ao uso, sintomas de abstinência e sintomas depressivos.

Descritores: Transtornos Relacionados ao Uso de Substâncias; Saúde da Mulher; Perfil de Saúde; Assistência Ambulatorial; Saúde Mental.

\section{RESUMEN}

Objetivo: caracterizar el perfil sociodemográfico y psiquiátrico de mujeres usuarias de sustancias psicoactivas en tratamiento para la dependencia química. Método: estudio descriptivo de abordaje cuantitativo realizado con mujeres atendidas en un Centro de Atención Psicosocial para Usuarios de Alcohol y otras Drogas (CAPS ad) del interior paulista. Resultados: la muestra fue de 349 mujeres adultas, solteras, baja escolaridad y desempleadas, usuarias de alcohol, cocaína, crack y tranquilizantes. Entre las consecuencias del uso incluyen el síndrome de abstinencia, sobredosis, síntomas depresivos y suicidas. La mayoría fueron encaminadas para el tratamiento por la familia o los servicios de salud. Casi el 20\% de estas mujeres ya habían iniciado tratamientos anteriormente. Conclusión: Los resultados sugieren acentuada morbilidad y altos niveles de vulnerabilidad psicosocial, que requieren una investigación minuciosa en la admisión de la usuaria, además de daños asociados al uso, síntomas de abstinencia y síntomas depressivos.

Descriptores: Trastornos Relacionados con Sustancias; Salud de la Mujer; Perfil de Salud; Atención Ambulatoria; Salud Mental. 


\section{INTRODUCTION}

The use of psychoactive substances by women is not a contemporary phenomenon, the fact is that in both genders, use has increased significantly, despite this, women still have a use three times lower than men ${ }^{(1-2)}$. The scientific literature shows evidence that women have more severe levels of addiction to alcohol and/or other psychoactive substances when they seek health care, so this group needs to be investigated and treated in its particularities ${ }^{(3-4)}$.

Recent studies point to the existence of socioeconomic, geographical, organizational and cultural barriers that expose the weaknesses in women's access to treatment services, which often tends to underestimate the reality of this problem in this group ${ }^{(5-6)}$.

It is noteworthy that, even though the use of psychoactive substances is lower among women, epidemiological surveys show an alarming increase in use by this group. Specifically in Brazil, use prevalence is considerable, such as alcohol (6.9\%) and tobacco $(9,0 \%)^{(7)}$, as well as cocaine use (smoked and inhaled) $(0.7 \%)^{(2)}$. According to II Brazilian National Alcohol and Drugs Survey, there was an increase in both prevalence and intensity of use among Brazilian women, especially the binge pattern, which represents an intake of four or more units of alcohol every two hours. This report showed that between the years 2006-2012 there was a $36 \%$ increase in the proportion of use in binge $\mathrm{e}^{(8)}$.

In addition, gender-specific characteristics and gender identity contribute to high morbidity and mortality rates in the population ${ }^{(3)}$. The complex interaction between the use of these substances and the various social, genetic, hormonal, cultural, neurophysiological and environmental factors make women more vulnerable to a more severe intoxication ${ }^{(4)}$, as well as a shorter period of time between first use and addiction ${ }^{(3)}$.

Although women accumulate innumerable risk factors, the specificities in the health-disease process of this group are not always observed in mental health care ${ }^{(9-10)}$. For example, while men tend to attribute more hedonistic meaning to substance use $^{(11)}$, women relate use to depression, feelings of social isolation, family and professional pressures, health problems, as well as various attempts to lose weight ${ }^{(12-14)}$.

Studies that investigate the use of alcohol and/or other psychoactive substances in women are the majority in portraying a sociodemographic profile of social exclusion, composed mostly of unemployed women, with low educational level, single, with no social support, victims of intrinsic violence to the phenomenon of the use of these substances $(3,9,13,15-16)$, and more vulnerable to the physical and psychiatric sequelae resulting from this interaction when compared to men ${ }^{(12)}$.

In this way, considering the complexity of the phenomenon and the social impact that the use of psychoactive substances entails in the life of the person, added to the increasing index of use, abuse and addiction in the female population, the investigations are still scarce ${ }^{(3)}$. In addition, initiatives to address topics relating to women's health and substance use are still incipient in psychoactive substance addiction treatment programs (detoxification and rehabilitation) $)^{(5-6,17)}$.

In the last decades, women were underrepresented in studies conducted in treatment settings and, consequently, this fact had an impact on the results of research. Differences between men and women were ignored, delaying the development of programs designed for female gender ${ }^{(5)}$. In programs aimed at women's health, these problems are relegated to invisibility ${ }^{(17)}$.

Knowing the profile of women users of psychoactive substances that seek treatment in specialized services is a necessary condition to improve nursing care, considering this situation one of the barriers that hinder the maintenance and adherence to the treatment of dependent women.

\section{OBJECTIVE}

To characterize the sociodemographic and psychiatric profile of women users of psychoactive substances in treatment for drug addiction.

\section{METHOD}

\section{Ethical aspects}

The study followed ethical standards and procedures in accordance with Resolution 466/2012, was approved by the Research Ethics Committee of the University of São Paulo at Ribeirão Preto College of Nursing.

\section{Design, place of study and period}

Descriptive study of a quantitative approach carried out in a Psychosocial Care Center for Users of Alcohol and Other Drugs (CAPS ad) in the state of São Paulo. The service offers service to users of all age groups and both genders, with mental disorders due to abuse and addiction to psychoactive substances, with emphasis on the prevention of relapse and harm reduction. The assistance is carried out by a multiprofessional team that works in an integrated way, with an assistance proposal that incorporates therapeutic and preventive activities.

\section{Population or sample; inclusion and exclusion criteria}

To compose the sample, a survey of service records was performed since the beginning of the service operation (1996), listing a total of 5889 (100\%) registered customers; of these, $843(14.3 \%)$ were women. From the application of the eligibility criteria, being aged 18 years old or older, being in the aforementioned service for the first time to treat addiction to alcohol or other psychoactive substances, a final sample of 349 (41.3\%) users was obtained.

To collect data, sociodemographic information and clinical and psychiatric profile were extracted from the patient records: use of psychoactive substances (in the last 12 months and last 24 hours, consequences of the use (symptoms of withdrawal syndrome and overdose), symptoms which were characterized by depression, suicide attempts, previous treatments, origin of referral to the referred service. The instrument was elaborated from the screening sheet used in the routine of the service. A formal authorization for the coordinators of the institution concerned was requested and granted.

\section{Analysis of results and statistics}

For statistical analysis a database was prepared in the Statistical Package Social Science (SPSS) version 19. Double typing was used to 
ensure the reliability of the data. The information was systematized in simple frequency, percentage and measures of central tendency.

\section{RESULTS}

The predominant characteristics of the sample were: adult women, age ranging from 18 to 73 years old, average of 32.2 years $(S d \pm 13,3)$, single, with low educational level, did not work, had their own residence, as shown by Table 1.

Table 1 - Sociodemographic characteristics of women using psychoactive substances under treatment ( $N=349)$, Ribeirão Preto, São Paulo, Brasil, 1996-2015

\begin{tabular}{|c|c|c|c|}
\hline & & $\mathbf{n}$ & $\%$ \\
\hline Marital status & $\begin{array}{l}\text { Single } \\
\text { Married/Consensual Union } \\
\text { Divorced/separated } \\
\text { Widower } \\
\text { Did not inform }\end{array}$ & $\begin{array}{l}188 \\
96 \\
33 \\
13 \\
19\end{array}$ & $\begin{array}{r}53.9 \\
25.7 \\
9.4 \\
3.7 \\
5.4\end{array}$ \\
\hline Education & $\begin{array}{l}\text { Complete / Incomplete Elementary School } \\
\text { Complete / Incomplete High School } \\
\text { Complete / Incomplete Undergraduate degree } \\
\text { Did not attend school. } \\
\text { Did not inform }\end{array}$ & $\begin{array}{l}195 \\
82 \\
18 \\
25 \\
29\end{array}$ & $\begin{array}{c}55.8 \\
23.4 \\
5.1 \\
7.1 \\
8.3\end{array}$ \\
\hline $\begin{array}{l}\text { Employment } \\
\text { bond }\end{array}$ & $\begin{array}{l}\text { Yes } \\
\text { No } \\
\text { Did not inform }\end{array}$ & $\begin{array}{c}97 \\
234 \\
18\end{array}$ & $\begin{array}{c}27.7 \\
67.0 \\
5.1\end{array}$ \\
\hline Dwelling & $\begin{array}{l}\text { Family's house or apartment } \\
\text { Parent's house or apartment } \\
\text { Did not inform }\end{array}$ & $\begin{array}{c}150 \\
112 \\
37\end{array}$ & $\begin{array}{l}42.9 \\
32.0 \\
10.6\end{array}$ \\
\hline
\end{tabular}

Regarding work, among those who worked in paid work, 48 (13\%) worked full time, but had no formal bond.

In the last 24 hours preceding the interview, one third had consumed alcoholic beverages or used some other type of psychoactive substances, being the highest use of alcohol 42 (36.2\%), marijuana 17 (4.8\%), crack 16 (4.5\%) and cocaine 11 (11.8\%).

Regarding the use of psychoactive substances in the last 12 months, there was a predominance of alcohol use, followed by cocaine and crack, as shown in Figure 1.

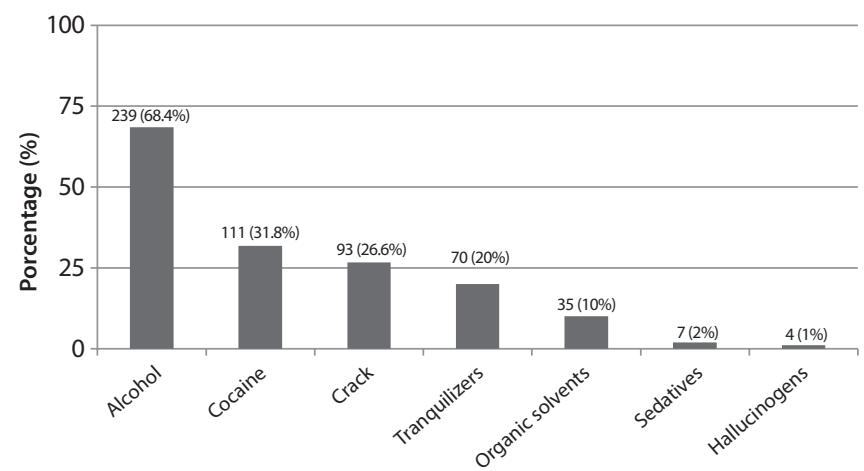

Figure 1 - Type of psychoactive substances used in the last 12 months, according to the women in treatment $(\mathrm{N}=349)$, Ribeirão Preto, São Paulo, Brasil, 1996-2015

Of the women, 180 (51.5\%) had signs and symptoms that may indicate some negative consequences of psychoactive substances such as: panic attacks 58 (32.2\%), heteroaggression 43 (23.9\%), fainting $30(16.7 \%)$, tongue twisting (12.8\%), seizure $13(7.2 \%)$ and overdose 8 (4.4\%).

In addition, 244 (69.9\%) women presented signs and symptoms of psychoactive substance withdrawal syndrome used, such as: 96 (27.5\%) insomnia, 87 (24.9\%) aggressive state, 74 (21.2\%) tremors and intense hand sweating, 54 (15.4\%) fissure, that is, an intense desire to use substances, 56 (16\%) visual or auditory hallucinations, 41 (11.7\%) lacrimation and intense yawning.

Of the depressive symptoms, $252(72.2 \%)$ of the women felt sadness to the point of not being able to perform their daily activities, 166 (47.5\%) had tried suicide at least once in their life and 122 (34.9\%) presented suicidal thoughts in the last two years.

Regarding previous participation in treatments, 159 (45.5\%) women had never sought health care for problems related to the use, abuse and addiction to psychoactive substances, 48 (13.7\%) had a medical visit at least once, and 26 (7.4\%) started treatment several times but did not conclude.

Figure 2 shows that 104 (29.7\%) women were referred to treatment by their own relatives and/or friends.

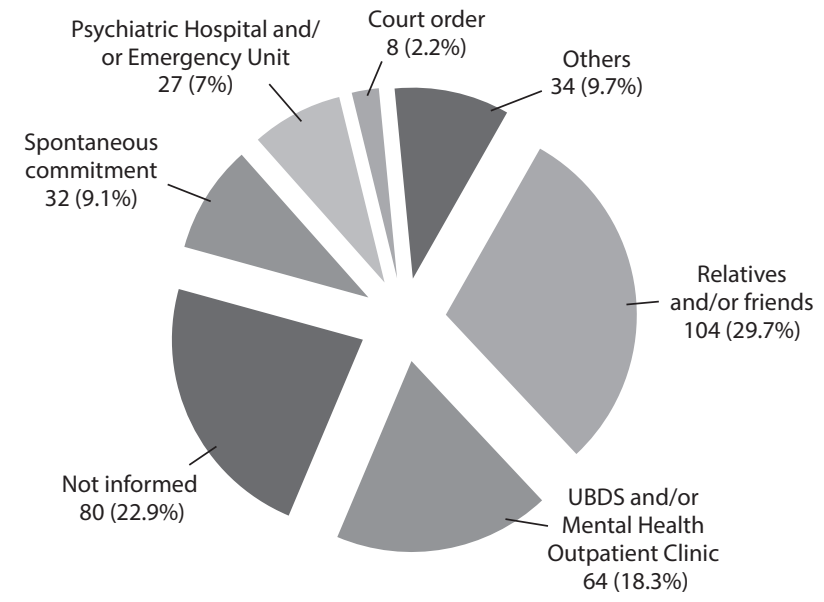

Figure 2 - Origin of referrals to specialized treatment, according to the women attended in CAPS-ad ( $N$ = 349), Ribeirão Preto, São Paulo, Brasil, 1996-2015

\section{DISCUSSION}

Women with psychoactive substance addiction have peculiar characteristics, however, as observed in this study, investigations conducted in similar services are unanimous in portraying a profile of women marked by biopsychosocial weaknesses, single, with low educational level, and without formal employment bonds $s^{(9,13,15)}$. This suggests that these services have served a socioeconomically disadvantaged population ${ }^{(18)}$.

The women in treatment were young (mean 32 years old). The literature shows that the average age of seeking treatment for women is 21 to 40 years old ${ }^{(14-15)}$. It is also added that between 2006 and 2013 there was an increase of 3.8\% per year in alcohol abuse for women aged between 30 and 39 years old ${ }^{(19)}$. A North American study that analyzed the cumulative probability of development of addiction in the course of life, found that women over the 44 years old present an increased chance of being dependent on alcohol, marijuana and cocaine ${ }^{(4)}$.

The age of the woman and the type of psychoactive substances used are indicated as factors of difference between women. In 
general, adolescent girls, besides using alcoholic beverages, use illicit substances such as marijuana, cocaine and crack cocaine, whereas older women prefer cigarettes, alcohol and medications, especially anorectics and tranquillizers ${ }^{(3,19)}$. The profile of women users of psychoactive substances is not only a consequence of the use, but also of the circumstances intrinsically linked to socioeconomic factors ${ }^{(16)}$, social-cultural environment, physiological peculiarities $^{(3,12)}$, and mainly by historical determination of the phenomenon, involving issues related to gender.

Occupational and educational levels are still factors of socioeconomic victimization among women, and reinforce the vulnerability of those who are addicted to psychoactive substances. Purchasing power shapes dependency, while men have access to a greater variety of substances because of income facilities, some women have access to prescription drugs, and cheap substances, often acquired through sexual intercourse $\mathrm{P}^{(13,16,20)}$.

As observed in the sample, the low educational level was predominant among women. Another study carried out with a female crack user identified that $77 \%$ of women had only primary education, and attributed this to school dropout, substance use and addiction, the need to work, and the onset of pregnancy ${ }^{(15)}$.

As for work, most did not work and among those who worked in paid work, most did not have a formal employment bond. A study with women users of crack in the city of São Paulo also presented a high rate of unemployment, $91 \%{ }^{(15)}$. It is worth noting that the precariousness of labor relations is often the result of low female empowerment and constitutes an additional factor of vulnerability, which keeps this group hidden from society's eyes and hinders access and adherence to treatment ${ }^{(17-18)}$.

The marital status identified among the women in this study, as well as in other research with women using psychoactive substances, showed that the majority were single. In this sense, it is necessary to consider other factors such as situations of intrafamily, physical and psychological violence ${ }^{(21)}$, or the condition aggravated by the use of substances, since women who use crack tend to social isolation ${ }^{(22)}$. A population study conducted in Brazil found that women tend to have less stable partners than men, $76.3 \%$, and $82.1 \%$, respectively ${ }^{(20)}$.

It is noteworthy that most of the women had their own dwelling, which can be seen as a protection factor because it provides a safe place to use and reduces the damage intrinsic to a possible street context. International study has identified dwelling as a safety enhancement, since it is a safer place where women can smoke crack with people they trusted and who would help keep them less vulnerable ${ }^{(13)}$.

The use with affective pairs was also identified in a national study ${ }^{(15)}$ performed with pregnant women using crack, however, this practice can often result in situations of various violence ${ }^{(13)}$. A review study in South American countries found that $10 \%$ of women reported that their partners were almost always intoxicated ${ }^{(23)}$.

Reflecting on the sociodemographic characteristics of this group, in the context of gender inequality, which constitutes a significant aspect of Brazilian society, it is apparent that health professionals, especially nurses, should make specific efforts so that such vulnerabilities are not barriers to access and continuity of care among women.

The first choice psychoactive substances among women was alcohol, both in the evaluation of use in the last 24 hours and in the last 12 months. It should also be noted the use of marijuana, cocaine and crack as the substances of choice, in the period preceding the initial consultation. National study showed that alcohol as the main substances of use and use pattern are directly related to retention and maintenance of treatment, daily use was more common among women who abandoned in the first month ${ }^{(9)}$.

Although there are regional and cultural variations in relation to access to different psychoactive substances, alcohol was the substance of greater use in the sample, data that corroborate those of national study ${ }^{(18)}$. A study identified that the substances most used in life were alcohol (91\%), marijuana (89\%), amphetamine $(86 \%)$, stimulants $(82 \%)$, crack/cocaine $(74 \%)$, sedatives $(55 \%)$, opioids (51\%), hallucinogens (46\%) inhalants $(27 \%)^{(14)}$.

The use of crack can also be conceived as a maladaptive strategy of managing negative physical or emotional symptoms experienced, since women tend to perceive that health services do not promote an effective understanding of their demands and experiences ${ }^{(13)}$. Approximately $72 \%$ of users accessing outpatient treatment services for addiction treatment experience significant life traumas ${ }^{(24)}$, particularly in women, the presence of trauma and the use of psychoactive substances often occur simultaneously ${ }^{(3,21)}$.

The acute symptoms of the use of psychoactive substances observed in the sample reinforce the already recognized biological singularities of the female gender. The literature shows that the use of these substances potentiates mental health problems and vice versa, such as anxiety, depression and sleep disorders, and more than half of women (50.8\%) do not seek professional help for treatment ${ }^{(13)}$.

Other life-threatening mental health diagnoses included antisocial personality disorder (63\%), anxiety disorders (42\%) and major depressive episode $(14 \%)^{(24)}$. In this way, specific programs for women are necessary, in order to minimize psychiatric symptoms and promote psychological well-being ${ }^{(17-18)}$.

From the psychiatric evaluation, depressive symptoms predominated (sadness, ideation or suicide attempt). This set of manifestations are very commonly associated with the use of alcohol and/or other psychoactive substances, can also mean physical and psychological suffering, and still have triggered the search for treatment. Women with psychiatric comorbidities (or dual diagnosis) are generally more likely to choose mental health services rather than substance abuse treatment services ${ }^{(3)}$. A national study that traced the profile of women treated in a CAPS-ad found that the reasons for the search for treatment were the demands arising from nervous, mental, psychiatric or psychological problems ${ }^{(21)}$.

The nursing professional should be sensitive to such needs and provide relief that supports the motivation of the user to engage in the search for help and maintenance of the treatment, increasing the state of readiness for behavioral changes in relation to the use of psychoactive substances and the self-care in health.

Regarding suicide attempts and thoughts, the literature indicates that individuals who abuse or are addicted to alcohol present such symptoms with higher frequency and higher risk, in addition to a greater number of attendance in health services, or due to clinical or psychiatric diseases ${ }^{(25)}$.

Regarding the treatment, although the first contact with the service was the criterion of selection of the sample, it was noticed that 26 women presented innumerable passages through hospital treatment units. Studies have identified that the average stay in treatment for women addiction was approximately 21 days $s^{(10,17)}$. 
A national study carried out in outpatient treatment for addiction, found a lower trend of abandonment of a participant in a psychosocial therapy group only for women compared to mixed groups $(10.2 \% \text { versus } 17.8 \%)^{(18)}$, although a review of the international literature showed that the composition of therapeutic groups did not influence the treatment outcome very much ${ }^{(3)}$.

In any case, the increase in auxiliary services for women, such as childcare, perinatal support and encouragement of potential sources of income, could improve women's access to treatment. Further research is needed to fill this gap in the literature, to identify interventions for the efficient treatment of substance abuse in the subgroup of women.

It is also added that women who completed the treatment and are accompanied by specialized treatment are $29 \%$ less likely to be arrested for involvement in substance trafficking or use $^{(10)}$, that is, maintaining unproblematic social interaction and consequent greater reintegration social.

The search for specialized care for the substance addiction observed in this study was through the intervention of the peers that make up the socio-cultural environment, such as family and friends. The social network of the individual has a fundamental role in the search for treatment and in the rehabilitation of the subject with mental disorder and/or user of psychoactive substances mainly among women ${ }^{(26)}$. Despite the psychological pressure that these same social components can exert, they are key supporters for problem detection and motivation for treatment in this group ${ }^{(21,26)}$.

Thus, planning health actions from a social network perspective constitutes a promising proposal for expanding early detection and seeking professional help before the symptoms are as severe as those presented in the sample studied.

\section{Limitations of the study}

The limitations of the study are the fact that it is a study based on secondary data, there may be low information reporting in these women's records, since the screening instrument often does not have scales, standardized questionnaires, to be used in the first consultation, which identifies not only the presence of symptoms, but not the intensity of the diseases.

\section{Contributions to the area of public health and nursing}

The study brings important contributions to the practice of Nurses and other health professionals in relation to the planning of actions regarding the use of psychoactive substances among women in different health settings.

\section{CONCLUSION}

Alcohol abuse was the most prevalent problem among women who were predominantly adult, single, with low educational level, with no formal employment bonds. Most of them had consequences associated with the use of psychoactive substances (panic attacks and episodes of heteroaggression), withdrawal symptoms (insomnia, aggressive state and fissure) and depressive symptoms, especially sadness, ideation and suicide attempt. These data suggest marked morbidity in a sample of women with high levels of psychosocial vulnerability, which require thorough investigation at the patient's admission.

The use of psychoactive substances by women is a complex and multifactorial topic. The factors predisposing to the maintenance of treatment in this group are still very little studied in the specialized services and need to be better explored in the literature.

\section{FUNDING}

This work was supported by the National Council for Scientific and Technological Development (CNPq) [Universal 14/2011 - Process 482442 / 2011-5] and the São Paulo Research Foundation (FAPESP) [Process 2009 / 14861-2].

\section{REFERENCES}

1. United Nations Office on Drugs and Crime (UNODC). World Drug Report 2016 [Internet]. Vienna: United Nations Publication; 2016 [cited 2017 May 09]. Available from: http://www.unodc.org/doc/wdr2016/WORLD_DRUG_REPORT_2016_web.pdf

2. Abdalla RR, Madruga CS, Ribeiro M, Pinsky I, Caetano R, Laranjeira R. Prevalence of cocaine use in Brazil: data from the II Brazilian National Alcohol and Drugs Survey (BNADS). Addict Behav. 2014;39(1):297-301. doi: 10.1016/j.addbeh.2013.10.019

3. Greenfield SF, Brooks AJ, Gordon SM, Green CA, Kropp F, McHugh RK, et al. Substance abuse treatment entry, retention, and outcome in women: a review of the literature. Drug Alcohol Depend. 2007;86(1):1-21. doi: 10.1016/j.drugalcdep.2006.05.012

4. Wagner FA, Anthony JC. Male-female differences in the risk of progression from first use to dependence upon cannabis, cocaine, and alcohol. Drug Alcohol Depend. 2007;86(2-3):191-8. doi: 10.1016/j.drugalcdep.2006.06.003

5. Prado MAM, Queiroz IS. A emergência da politização da intimidade na experiência de mulheres usuárias de drogas. Estud Psicol. 2012;17(2):305-12. doi: 10.1590/S1413-294X2012000200015

6. Silva PL. Mulheres usuárias de substâncias psicoativas: barreiras de acessibilidade em um CAPS AD [Dissertação] [Internet]. Salvador: Universidade Federal da Bahia; 2013 [cited 2018 Feb 10]. Available from: http://bdtd.ibict.br/vufind/Record/UFBA-2_06685110b0de8a3f1a8be48c1a0246b7

7. Galduróz JCF, coordenador. II Levantamento Domiciliar sobre o Uso de Drogas Psicotrópicas no Brasil: estudo envolvendo as 108 maiores cidades do país [Internet]. São Paulo: Centro Brasileiro de Informação sobre Drogas Psicotrópicas (CEBRID); 2006 [cited 2017 May 09]. Available from: https://www.cebrid.com.br/wp-content/uploads/2014/10/II-Levantamento-Domiciliar-sobre-o-Uso-de-DrogasPsicotr\%C3\%B3picas-no-Brasil.pdf 
8. Laranjeira R, organizador. II Levantamento Nacional de Álcool e Drogas. O consumo de álcool no Brasil: tendências entre 2006-2012 [Internet]. São Paulo: Instituto Nacional de Políticas Públicas do Álcool e Outras Drogas (INPAD); 2014 [cited 2018 Feb 10]. Available from: http://inpad.org.br/wp-content/uploads/2013/04/LENAD_PressRelease_Alcohol_RVW.pdf

9. Elbreder MF, Laranjeira R, Siqueira MM, Barbosa DA. Perfil de mulheres usuárias de álcool em ambulatório especializado em dependência química. J Bras Psiquiatr. 2008;57(1):9-15. doi: 10.1590/S0047-20852008000100003

10. Kissin WB, Tang Z, Campbell KM, Claus RE, Orwin RG. Gender-sensitive substance abuse treatment and arrest outcomes for women. J Subst Abuse Treat. 2014;46(3):332-9. doi: 10.1016/j.jsat.2013.09.005

11. Martin G, Macdonald S, Pakula B, Roth EA. A comparison of motivations for use among users of crack cocaine and cocaine powder in a sample of simultaneous cocaine and alcohol users. Addict Behav. 2014;39(3):699-702. doi: 10.1016/j.addbeh.2013.10.029

12. Dow-Edwards D. Sex differences in the effects of cocaine abuse across the life span. Physiol Behav. 2010;100(3):208-15. doi: 10.1016/j. physbeh.2009.12.017

13. Bungay V, Johnson JL, Varcoe C, Boyd S. Women's health and use of crack cocaine in context: Structural and 'everyday' violence. Int J Drug Policy. 2010;21(4):321-9. doi: 10.1016/j.drugpo.2009.12.008

14. Warren CS, Lindsay AR, White EK, Claudat K, Velasquez SC. Weight-related concerns related to drug use for women in substance abuse treatment: Prevalence and relationships with eating pathology. J Subst Abuse Treat. 2013;44(5):494-501. doi: 10.1016/j.jsat.2012.08.222

15. Nappo SA, Sanchez Z, Oliveira LG. Crack, AIDS, and women in Sao Paulo, Brazil. Subst Use Misuse. 2011;46(4):476-85. doi: 10.3109/10826084.2010.503480

16. Galea S, Vlahov D. Social determinants and the health of drug users: socioeconomic status, homelessness, and incarceration. Public Health Rep [Internet]. 2002 [cited 2018 Feb 10];117(Suppl 1):135-45. Available from: https://www.ncbi.nlm.nih.gov/pmc/articles/PMC1913691/

17. Rasch SS, Andrade AN, Avellar LZ, Ribeiro Neto PM. Projeto Terapêutico Singular no atendimento de mulheres em um CAPS AD III. Psicol Pesq. 2015;9(2):205-15. doi: 10.24879/20150090020010

18. Peixoto C, Prado CHO, Rodrigues CP, Cheda JND, Mota LBT, Veras AB. Impacto do perfil clínico e sócio demográfico na adesão ao tratamento de pacientes de um Centro de Atenção Psicossocial a Usuários de Álcool e Drogas (CAPSad). J Bras Psiquiatr. 2010;59(4):317-21. doi: $10.1590 /$ S0047-20852010000400008

19. Munhoz TN, Santos IS, Nunes BP, Mola CL, Silva ICM, Matijasevich A. Tendências de consumo abusivo de álcool nas capitais brasileiras entre os anos de 2006 a 2013: análise das informações do VIGITEL. Cad Saúde Pública. 2017;33(7). doi: 10.1590/0102-311x00104516

20. Diehl A, Vieira DL, Rassool GH, Pillon SC, Laranjeira R (2014) Sexual behaviours and condom use in a sample of Brazilian crack cocaine smokers. J Addict Behav Ther Rehabil 3:2. doi: 10.4172/2324-9005.1000120

21. Pillon SC, Santos MA, Florido LM, Cafer JR, Ferreira PS, Scherer ZPA, et al. Consequências do uso de álcool em mulheres atendidas em um Centro de Atenção Psicossocial. Rev Elet Enf. 2014;16(2):338-45. doi: 10.5216/ree.v16i2.22712

22. Prinzleve MA, Haasen CA, Zurhold HA, Matali JLB, Bruguera EB, Gerevich J. Cocaine use in Europe - a multi-centre study: patterns of use in different groups. Eur Addict Res. 2004;10(4):147-55. doi: 10.1159/000079835

23. González-Guarda RM, Peragallo N, Lynch A, Nemes S. Drugs, Women and Violence in the Americas: U.S. Quantitative Results of a MultiCentric Pilot Project (Phase 2). Rev Colomb Psiquiatr. 2010;39(Suppl):66-83s. doi: 10.1016/S0034-7450(14)60268-7

24. Gunter TD, Philibert R, Hollenbeck N. Medical and psychiatric problems among men and women in a community corrections residential setting. Behav Sci Law. 2009;27(5):695-711. doi: 10.1002/bsl.887

25. Ponce JC, Andreuccetti G, Jesus MGS; Leyton V, Muñoz DR. Álcool in vítimas de suicídio em São Paulo. Rev Psiquiatr Clin. 2008;35(Suppl 1):13-6. doi: 10.1590/S0101-60832008000700004

26. D'Orio BM, Thompson MP, Lamis DA, Heron S, Kaslow NJ. Social Support, attachment and drug misuse in suicidal African American women. Addict Res Theory. 2015;23(2):170-6. doi: 10.3109/16066359.2014.966096 